\title{
The Legal and Administrative Context of Environmental Policy in Mexico City 1
}

\author{
By Brigitte F. P. Lhoëst
}

\section{Introduction}

Like so many urban centers, Mexico City is fraught with large and increasing environmental problems. However, Mexico City's problems are compounded by its geographical location, notably its high altitude and the fact that it is surrounded by a mountain chain.2

The following data ${ }^{3}$ serve to give a brief indication of the multifold sources of pollution: on a territory of some 7.770 square kilometres there is a population of approximately 18 million persons (estimated annual average grow rate 1,8 percent) with a population density in the Federal District, the heart of Mexico City, of 160 Persons per hectare. Together they represent 25 percent of Mexico's economically active population (40 percent of this group is officially not registered as employed but works in the grey or black circuit) accounting inter alia for 46 percent of the total industrial production. The public investments per capita in the capital are twice as high as in the rest of the country.

The ecological consequences of the explosive expansion of the population 4 and of the fast industrial growth have proven a disastrous burden upon the amount of clean water, air and soil a vailable. To give an impression 5 : there is the loss of 99 percent of the lacustrine area,

1 I would like to express my gratitude to Lucio Cabrera Acevedo, Head of the Historic Commission of Mexico's Supreme Court and Maria del Carmen Carmona Lara, Researcher at the UNAM, for the useful information they provided me on Mexican environmental law in theory and practice, and furthermore to my colleagues, Jan Michiel Otto and Sebastian Pompe, at the Van Vollenhoven Institute for Law and Administration in Non Westem Countries for their helpful comments.

2 Situated in a semiclosed montane basin at an altitude of 2.400 meters above sea level, Mexico City is highly susceptible to thermal inversions that trap air pollution at ground level.

3 Data from Peter $M$. Ward, Mexico City, the production and reproduction of an urban environment, Belhaven Press, London 1990.

4 From a total population of 19,6 million in 1940 to an estimated 69,7 million in 1980 , to 84,5 million in 1989. There was an average growth rate of 2,2 percent between 1980 and 1988 . The proportion of the national population living in urtan areas rose from 22 per cent in 1940 to 42,3 per oent in 1970, to 55 per cent in 1989, data from: Daniel Hiernawx Nicolos, Servicios urbanos, grupos populares y medio ambiente in Chalco, México, in: Martha Schteingart / Luciano d'Andrea, Servicios Unbanos, Gestión Local y Medio Ambiente, ElColegio de México 1991.

5 Dates from: María del Carmen Carmona Lara, Reflexiones para el establecimiento de un código urhano para el Distrito Federal, Boletín Mexicano de Derecho Comparado, Año XX no. 601987. pp. 875-885. 
the water usage is 36,6 cubic meter per second of which only 1,6 cubic meter is recycled, 20 percent of Mexico City's population does not dispose of piped drinking water and three million inhabitants do not dispose of a drainage system. Regarding the soil: there is the loss of 73 percent of its woodlands, and still hundreds of hectares are deforestated each year, the green areas per person averages rount 2,7 square meters per person. Last but not least the air pollution: it is estimated that the three million vehicles circulating daily through Mexico City's streets 6 account for 76 percent of all contaminants released in the atmosphere of Mexico City. 7

The complexities of environmental issues facing the Mexican authorities are matched if not outdone by the convoluted govemmental and legislative structures in place to deal with them. It is the aim of this article to demonstrate that the fragmentation of legal authority to deal with environmental problems in Mexico effectively vitiates an adequate govemment response towards containing let alone solving environmental problems. For this purpose regard will first be had to the development of the national Mexican legislation conceming the environment on Federal level. Next, the environmental legislation of Mexico City will be considered. Finally the consequences of the present fragmentation of legislative power regarding the environment will be contemplated.

Because of the recent origin of this new field of Mexican law, there is scarcely a vested doctrine or case law on the issue. The emphasis of my investigation therefore lies on the legislation: the Mexican Constitution of 19178, the Organic Law on the Public Administration of 19769, the Organic Law of the Department of the Federal District of 197810, the General Law of Ecological Balance and Environmental Protection of 198811 and subsequent regulations.

6 It is estimated that 29,5 million trips per person are made every day, in 2.549 .020 private automobiles, 136.112 taxis and public-transport minibuses, 10.950 city buses, 8 Metro lines with 2.205 subwaycars, one light train line and 450 electric trolleycars. It is also estimated that 96 thousand delivery trucks using gasoline circulate within the Metropolitan Zone, as well as 60 thousand trucks using diesel fuel to carry passengers and freight from outside the city. Dates from Mexican Agenda, Embassy of Mexico 1992.

7 There is a yearly emission of more than four million tons of pollutants; 153 thousand particles; 3 million 720 thousand tons of carbon monoxide; 520 thousand tons carbohydrates, 411 million tons of nitrogen oxides and 132 million tons of sulfur oxides. Dates from GACETA UNAM, 10-8-1992 no 2671.

8 Mexican Constitution of 1917, as reformed in the Diario Oficial (D.O.) December 1992.

9 Organic Law on the Federal Public Administration, published D.O. 29-12-1976, latest reformed D.0. 25-6-1992.

10 Organic Law of the Department of the Federal District, published D.O. 29-12-1978.

11 General Law of Ecological Balance and Environmental Protection, published D.O. 28-1-1988. 


\section{The National Environmental Legal Framework}

\subsection{Constitutional Franework}

Mexico is a federal Republic, composed of States which are free and sovereign in all that concems their internal government but united in a Federation according to the principles of the 1917 Constitution. 12 Governmental power between the States and the Federation was (and still is) divided in such a way that all powers which the Constitution does not expressly grant to the Federation are understood to be reserved to the States. 13

Within this structure Mexico City h as a separate status. It is neither a State nor an ordinary municipality 14 but it consists of a separate political and administrative entity in its own right, the Federal District falling directly under the authority of the Federal Government ${ }^{15}$, and in addition there is a Metropolitan Zone composed of eighteen co-urban municipalities, falling under the direct authority of two separate States, the State of Mexico and the State of Morelos 16. Schematically governmental power is divided thus:

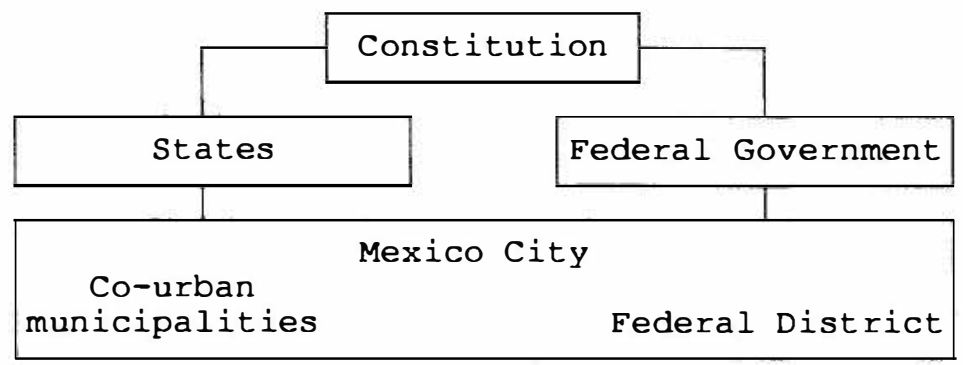

12 Ar. 40 Mexican Constitution of 1917.

13 Ar. 124 Mexican Constitution.

14 In the Mexican govemment system the municipality stands at the basis of the territorial division of the political and administrative organization. Each municipality is administered by a council (Ayuntamiento) elected by direct popular vote. The councils are empowered to issue regulations, circulars and administrative orders for general compliance within their respective jurisdiction, see ants. 115, 116 of the Constitution and Pedro Emiliano Hernández-Gaona, Derecho municipal, UNAM México 1991.

15 According to ar. 73 VI of the Constitution the Congress has the power to legislate on all matters regarding the Federal District and the govemment of the Federal District is entrusted to the President of the Republic.

16 With Mexico City is meant, the Federal District and the Metropolitan 7one; the federal District, consists of 16 political delegations $\left(1.500 \mathrm{~km}^{2}, 10\right.$ million persons) and the Metropolitan Zone, consists of 17 municipalities situated in the State of Mexico (1782 km2,8 million persons) and one municipality situated in the State of Morelos. Hector Castillo Berthier, Desechos, Desperdicios: Sociedad u Suciedad, in: Martha Schteingart / Luciano d'Andrea, Servicios Unbanos, Gestión Local y Medio Ambiente, El Colegio de México 1991. 
A fundamental problem is that the 1917 Constitution did not at first state in unequivocal terms that the Federation was empowered to regulate for the 'environment', which consequently was a domain to be regulated separately by each and every member State. Nevertheless, this division of powers with time has revealed itself to be singularly inadequate as an answer to environmental problems, notably when environmental issues have crossed State boundary lines. Mexico City is a case in point, its area being not only situated in two separate States but also in a third separate governmental entity, that of the Federal District. As the necessity for more wholesale measures became ever more apparent, there have been growing pressures for the Federal Government to regulate the environment. Still and whilst this involvement materialized as we shall see next, at least until the Constitutional Amendment of 1987 the weak constitutional basis for federal involvement in environmental issues fragmented govemment response towards environmental problems. This fragmentation has conditioned the legislative structures to the present day.

Prior to the 1987 Amendment, the Federal Govemment sought to circumvent the restrictions imposed by the constitution by an extensive interpretation of art. 27 of the 1917 Constitution. This article, which affirms that the ownership of the lands and waters within Mexico is vested originally in the Nation, disposed among others that the Federation at all times has the right to take necessary measures to prevent the destruction of natural resources. This clause has formed the constitutional basis for a succession of regulations conceming water, woods, soil, energy generation, hydrocarbons, fishieries and hunting, which were the direct precursors of the present environment laws.

The first reform of the Mexican Constitution with regard to the upcoming Problem of pollution dates from 1971. In art. 73 section XVI17, the Public Health Council, falling under the direct authority of the president, was empowered to take the necessary measures to prevent and combat the environmental pollution that presented a threat to public health. From this reform emanated the same year the first Federal Law to Prevent and Control Environmental Pollution. 18 The new law provided formal bases for the executive branch to enact and implement regulations in the environmental area. Several regulations were promulgated in 1971 and 1973 to implement the new law, inter alia addressing aspects of air and water-quality problems by prescribing antipollution controls in industry, regulating vehicular emissions and spedifying standards for the quality of surface and coastal water.

17 Ar. 73 fraction XVI, D.O. 6-7-1971: "The Public Health Council shall be directly subordinated to the President of the Republic ... its general provisions shall be obligatory throughout the country and the measures which the Council adopts to prevent and combat envinonmental pollution shall af terwards be examined by the Congress of the Union, in cases within its competency ..." Published D.O. 23-3-1971. 
Furthermore they established penalties for violators of the abovementioned law and regulations. 19

Administratively, the environmental policy was further elaborated in a newly created under-ministry within the Ministry of Health: the Under-ministry for the Improvement of the Environment (SMA)20. This agency was in charge of the implementation of the Federal Law of 1971 and coordinated the activities of other government institutions on environmental matters. It was mostly working on public health and education, next to enforcing environmental sanctions and licensing new industries. However, despite the creation of SMA, administration remained dispersed over at least five separate ministries 21 , supplemented by autonomous agencies like Petroléos Mexicanos (PEMEX) and by certain implied tasks for States and municipalities.

Slowly the environmental problems gained ground on the govemmental agenda22 and on the 11th of February 1982 a new law was enacted: "The Federal Law to Protect the Environment". The new law substantially reinforced the earlier one. Some new chapters were added, conceming problems such as marine pollution, radioactive hazards, and the contamination of air, water and soil. An important innovation was the chapter on new possibilities for "popular action" (Denuncia Popular) which created procedures for citizens to complain and initiate action against violators of this law. With the enactment of the Federal Law to Protect the Environment of 1982, the administrative and executive competences regarding the environment were transferred to a new ministry, the Ministry of Urban Development and Ecology23 (SEDUE), which combined the portfolios for housing and environment into a single cabinet-level ministry. The ministry's mandate embraced that of its predecessor, SMA, but it also incorporated former units of the Ministry of Human Settlements and Public Works and the Ministry of Agriculture and Hydraulic Resources, and extended coordinating authority over environment related functions of other

19 See the Regulation for the Prevention and Control of Atmospheric Pollution by Smoke and Dusts of 1971 and the Regulation for the Prevention and Control of Water Pollution of 1973.

20 The "Subsecretaría de Mejoramiento del Ambiente" (SMA) was established by presidential decree D.O. 29-1-1972.

21 See Stephen P. Munne / C. Richard Batz / Valerie J. Asseto, Political development and environmental policy in Mexico, Latin American Research Review, Vol. 23 no. 11988.

22 This was largely due to the increased popular pression, by 1980 professional as well as civic groups in Mexico City were strongly criticizing govemment's performance regarding the environment. See Stephen P. Munne / C. Richard Batz / Valerie J. Asseto, Political development and environmental policy in Mexico, Latin American Research Review, Vol. 23 no. 1 1988, and Wade Graham, MexEco? Mexican Attitudes Toward the Environment, Environmental History Review, Vol. 15 1991, pp. 1-30.

23 Reform of anicle 37 of the "Organic Law on the Federal Public Administration" by presidential Decree published D.O. 29-12-1982. Interior Reglementation of the new Ministry, D.O. 19-8-1985, reformed D.O. 23-12-1988. 
agencies. $^{24}$ Within SEDUE a special environmental division was created: the Underministry of Ecology25.

The effectiveness of the Federal Environmental Law was limited. Its implementation was hampered by an ongoing debate on whether the Federal govemment had not in fact exceeded its constitutional authority. This lingering constitutional unclarity contributed to the limited ambit of the Federal Law, which was essentially individually repressive, rather than generally preventive. The Federal law only aimed at control of environmental polluion by way of sanctioning individual illegal acts. The law is marked by a complete disregard for the economic and social conditioning of environmental problems and did not in any way propose a more comprehensive approach towards tackling environmental issues in a more general way. There was no conception whatsoever in the law of economic development balanced with natural resources and environment. 26

Constitutional amendments in 1983 and 1987 marked a new line of thinking about the environment. In 1983, with the revision of aricle 2527 it was explicitly stated that in future national development programs economic progress could be adapted to suit the modalities ensuring conservation of the productive resources as well as the environment.

In 198728, first of all with the amendment of art. 27, the principle of conservation and protection of natural resources was further elaborated:

"the Federation at all times has the right to impose on private property such limitations as the public interest may demand, like the regulation of the utilization of natural resources. With this end in view the Federation may take the necessary measures to preserve and restore the ecological balance".

24 Nevertheless, subsidiary functions were stilldesignated to almost every ministry in the govemment causing many jurisdictional and operational difficulties. See also: Rainer Godau Schucking, La protección ambiental em México: sobre la conformación de una política pública, Estudios Sociológicos, Vol. III 1985, pp. 47-84.

25 An important impediment for the Underministry of Ecology was its lack of an adequate budget; its 1983 budget for pollution control and ecology totalled seven million dollars which was some two percent of the SEDUE's entire allocation. See: Stephen P. Mumme / C. Richard Batz / Valerie J. Asseto, Political development and environmental policy in Mexico, Latin American Research Review, Vol. 23 no. 11988.

26 In fact, structural adjustment policies during the govemment period of La Madrid (1982-1988) were designed to cut govemment spending, so environmental, health and safety programs were sharply reduced. See: Daniel Goldrich / David V. Carrushers, Sustainable development in Mexico?, Latin American Perspectives, Vol. 19 No. 11992.

27 Published D.O. 6-8-1983.

28 Reforms of arts. 27 and 73 fraction XXIXX G Mexican Constitution, published D.0. 11-8-1987. 
Secondly, in article 73 fraction XXIX G a decentralisation of the environmental regulation and environmental administration was foreseen. To end all conflicts about the question of competences, the Federal Congress now was empowered to expedite laws that would establish the competence of the Federal Govemment, the Govemments of the States and the municipalities, in the areas of their respective powers, with regard to environmental protection and the preservation and restoration of the ecological balance.

With remarkable speed the "General Law of Ecological Balance and Environmental Protection" (LGEEPA)29 appeared in 1988. Examining this law, which establishes the framework of the present Mexican legislation on the environment, there are two things that strike the eye; first of all the law aims at decentralizing power to regulate the environment, and secondly, the law only offers a rough framework and does not offer explicit environmental noms.

Although on the one hand the law intends to decentralize govemmental authority and to give the States and the municipalities their own responsibilities, on the other hand it still is the federal administration that holds the main authority. As stated in article 4 section 1 LGEEPA:

"All matters of general extent regarding the nation or in the interest of the Federation belong to the competence of the Federation".

Article 5 demonstrates that "matters of general extent" cover a very wide area indeed, thus the Federal Authorities are competent in such diverging matters as:

the formulation and directing of the general ecological policy; the formulation of the general ecological criteria which must be observed for the protection of natural areas and the marine and wild flora and fauna, for the use of natural resources, for the ecological ordering of the territory and for the prevention and control of pollution of the water, air and soil; the prevention and control of environmental emergencies and contingencies, the regulation of activities that are considered highly dangerous to the environment, the creation and administration of protected natural areas, the protection of the atmosphere in zones or from sources that fall under the federal jurisdiction and so on.

According to art. 6 the States and municipalities are competent in local matters such as:

the preservation of the ecological balance and the protection of the environment of property and territories that fall within the local jurisdiction, the regulation of activities that are not considered highly dangerous, the regulation and conservation of urban 
parks, the prevention and control of atmospheric pollution generated in zones or by sources that belong to the State or municipal jurisdiction 30 and so on.

The fact that powers now have been more clearly demarcated than before, that is to say that at least the legislative void that existed is bridged by defining more clearlywhat the federal authorities are allowed to regulate, has enabled the Federal as well as the State and municipal authorities to start regulating diverse environmental problems.

Substantively, the law gives definitions and concepts of the different forms of pollution, but does not really go into normative prescriptions. Thus the law needs to be implemented by federal and local laws and regulations. 31 Since 1988 the General Law has been complemented by the adoption of four specific regulations:

the Regulation to the Law for the Prevention and Control of Atmospheric Contamination 32; the Regulation to the Law for Hazardous Waste33; the Regulation to the Law for Environmental Impact34; and the Regulation to the Law for the Prevention and Control of Pollution Generated by Motor Vehicles that Circulate in the Federal District and Surrounding Municipalities 35 .

Furthermore there have been issued some eighty technical standards to determine the maximum permissible limits for emission and discharge of pollutants, the procedures and specifications regarding water, air and land pollution, as well as other ecological criteria.

Acting within the sphere of their competences 29 of the 31 States have enacted a State law on the protection of the environment.

30 To know what is understood by territories, zones and sources that fall under State or municipal jurisdiction, it is useful to look at an. 115 of the Constitution that determines that inter alia the following public services belong to the jurisdiction of the States and Municipalities: the drinking water and sewage system, public lighting, trash collection, storage warehouse, streets, parks and gardens, public safety and transporation.

31 This phenomenon is no new, often Mexican regulatory laws tend to be "purposefully vague", leaving the authority for implementation in the hands of the Mexican Executive, see: John FH. Purcell / Susan Kaufman Purcell, Mexican Business and Public Policy, in: James M. Malloy (ed.), Authoritarianism and Corporatism in Latin America, Pitusburgh 1977.

32 Published D.O. 25-11-1988.

33 Published D.O. 25-11.1988.

34 Published D.O. 7.6.1988.

35 Published D.O. 25-11-1988. 


\subsection{Federal Institutions}

With time, the SEDUE Ministry revealed itself to be weak as a policy implementing institution. It was by and large occupied with the drafting of new laws and regulations and neglected the implementation and control of the observance of the new rules.36 This lay at the root of the reorganisation of the SEDUE Ministry37 into the new "Ministry of Social Development" (SEDESOL) ${ }^{38}$. The new Ministry covers three areas: regional development, urban development and public housing.

The ministry's main tasks regarding the environment according to art. 32 of the Organic Law on Public Administration are:

to formulate, conduct and evaluate the national policy concerning social development in general and the environment in particular; to promote the ecological ordering of national gerritory as an efficient element of environmental protection; to formulate and conduct the policy regarding environmental sanitation in coordination with the Ministry of Health; to establish norms for the use of natural resources; to determine norms and execute actions that ensure the conservation and restoration of the fundamental ecosystems in particular in situations of emergencies and contingencies; to guard the compliance to the norms through competent organs and to establish mecanisms, instances and administrative procedures to reach this goal; to regulate the rational use of the wild and marine flora and fauna; to establish ecological criteria and general noms for the disposal of waste water, as well as to guard that these norms are complied; to propose to the Federal Execulive the establishment of national protected natural areas and to promote the participation of local authorities in their administration; to evaluate the manifestation of the Environmental Impact; and to promote, develop and realize research related with the ecology.

It is remarkable that SEDESOL does not have an under-ministry that occupies itself exclusively with environmental affairs but that instead regarding her environmental tasks

36 See: Daniel Goldrich / David V. Carrushers, Sustainable development in Mexico?, Latin American Perspectives, Vol. 19 No. 1 1992: "SEDUE is reported to have has just nine inspectors available in 1990 to enf orce the law for 35,000 metropolitan industries".

37 However, there also were other political reasons to change the structure; SEDUE emerged as a most politized ministry. During 1982 and 1988 four cabinet ministers held portfolio at SEDUE, two of them resigning under pressure, while the Subministry of Ecology changed hands twice. Interview with: Artwo Alcocer Lujambio, Sub Attomey of Social Participation and Complaints SEDESOL, and María del Carmen Carmona Lara, Ganó el concepto de desarrollo al concepto de ecología, ECOlógicas Año 3 no. 2 1992, pp. 5-8, and an unpublished pater by Jolle Demners / B. Hogenboom, Popular Organization and Party Dominance, Faculty of Political and Socio-Cultural Sciences, University of Amsterdam, November 1992.

38 See the Decrees published in the D.O. 25-5-1992 and D.O. 4-6-1992 for the Intemal Reglementation of the Secretary of Social Development. 
the new ministry has two rather autonomous deconcentrated branches seeing to environmental policy formulation and implementation: the National Ecological Institute and the Attomey General's Office for Environmental Protection. The National Ecology Institute among others has the authority to: formulate, conduct and evaluate the general ecological policy; to promote the ecological regulations on the national territory in coordination with the corresponding federal, state and municipal administrative entities and with participation of the private sector; and to grant licenses, concessions and authorizations within the sphere of its competences. The Attomey General's Office for the Protection of the Environment is charged with the vigilance and control of compliance with the federal environmental regulations.

\section{Organizational structure SEDESOL}

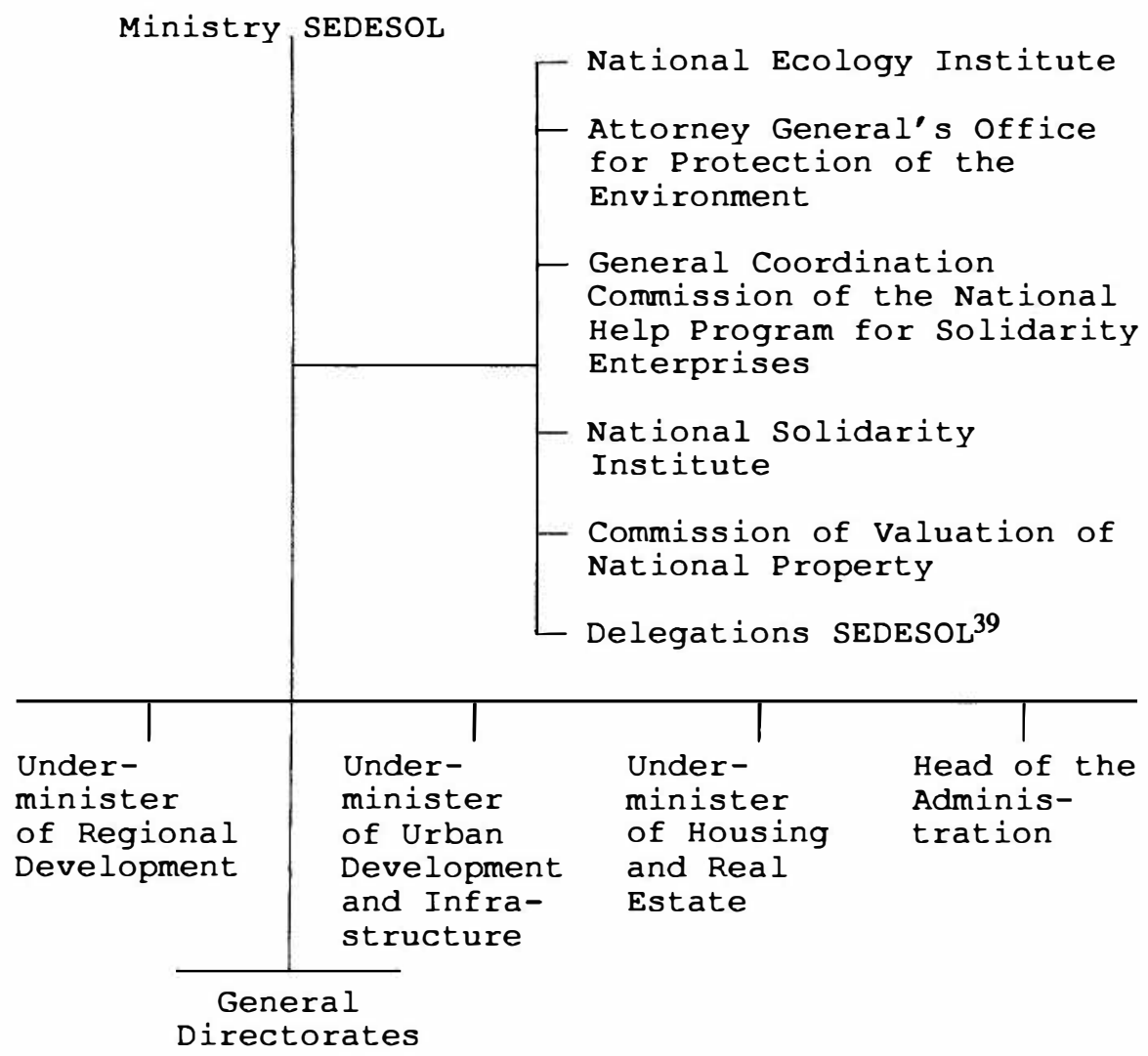

39 The SEDESOL delegations consist of local representatives of SEDESOL in the different States. 
It must be noted that although it is the Ministry of Social Development that has the main authority regarding environmental affairs it is not the only ministry that occupies itself with this subject. The Ministries of Health, Agriculture and Hydraulic Resources, and of Fisheries also participate in the exercise and above in all the application, operation and vigilance of norms related to specified environmental aspects such as protected natural areas, flora and fauna and waste waters.

Hence, it seems to be likely that the inherent existence of fragmentation and comparmentalization at the uppermost administrative levels in combination with the specific Mexican discretionary style of decision-making will continue to produce bureaucratic infighting, duplication of functions and policy incoherence and ineffectiveness. 40

\section{Mexico City's Environmental Legal Framework: Laws and Institutions}

As we shall see in the next sections, the above sketched problems regarding the scattered legal framework and institutional structures on national level all culminate on Mexico City's 7.770 square kilometers.

\subsection{The Federal District}

Mexico City's Federal District occupies a special position in the state administration. As the seat of the federal powers it is, as I mentioned before, neither a State nor a municipality but a separate political entity on its own territory. It is govemed by the Federation, meaning that the executive and legislative power over the Federal District belongs to the competence of respectively the President and the Federal Congress;

- the President exercises his authority through conduct of the Head of the Department of the Federal District (El Regente), who is assisted by sixteen local mayors (delegados);

- the Legislative power over the Federal District in first instance lies with the Federal Congress 41 , acting as local Congress. In order to give the local population more direct influence

40 See John F H. Purcell / Susan Kaufman Purcell, Mexican Business and Public Policy, in: James M. Malloy (ed.), Authoritarianism and Corporatism in Latin America, Pittsburgh 1977, and Merilee F. Grindle, Bureaucrats, politicians and peasants in Mexico: a case study in public policy, University of Calif omia Press 1977.

41 Ar. 73 VI of the Mexican Constitution. Thus, in the Federal Distria, the legislative branch does not consist of representatives chosen locally by the cirizens of the Federal Distric but of representatives chosen by the citizens of the whole nation. In general, projects of laws or reglementations materially are prepared by the General Secretaries of the Department of the Federal District whereupon the Mayor submits it to the President who in his tum, after careful revision sends it to Congress to stan the legislative procedure. In the Chamber of Deputies a special commission is 
on local policy and legislation an additional tier ${ }^{42}$ has been created in 1987, the Assembly of Representatives of the Federal District 43. The Assembly consists of 66 representatives chosen in direct elections by the cilizens of the Federal District. Its main tasks are to issue policy and good government decrees, statutes and regulations, to supervise the management of public resources and to approve the nomination of the local judiciary in the Federal District.

Hence, it belongs to the competence of the Assembly to enact local laws and regulations regarding the preservation of the environment and ecological protection. 44 However, the Federal Authorities have kept their influence; in the same article 73 of the Constitution that establishes the faculties of the Assembly another section (XXIX G), determines that the Federal Congress is empowered:

charged with examining, revising and elaborating the legislation of the Federal Districa. This commission is mainly constituted of Deputies originating from the electroral district of the Federal District. Thus the legislation of the Federal District is formally enacted by the Federal Congress. As legislator of the Federal District the Federal Congree enacts for instance the civil, commercial and criminal codes for the Federal District.

42 Formerly there already was an organ, the Consultative Council, consisting of representatives of local enterprises, interest groups, lobbies, resident associations etc, by which the local population theoretically could present the Mayor with projects of laws, reglementations and reforms and derogations of existing laws and reglementations, however this instance did not carry much influence.

43 Constitutional reform of an. 73 fraction VI, as published in the D.O. 10-8-1987.

44 The most important of the powers of the Assembly of Representatives for the Federal Distria are:

A) - As single Legislator. enact police and good govemment decrees, statutes and regulations, that without violating that which is regulated by the laws and decrees made by Congress of the Union for the Federal Districa, aim to tender the needs as manifested by the inhabitants of the Federal District in matters of: education, health and social assistance; supply and provision of food, markets and mercantile establishments; commerce in public road areas; recreation, public shows and sports; public security, civil protection; auxiliary services to the administration of justice; social prevention and readaptation; use of the soil, preservation of the environment and ecology protection and so on.

- As collaborator of the Federal Congress: they can initiate before the Federal Congress, laws or Decrees in matters related to the Federal District.

B) Propose to the president of the Republic the attention to priority problems, so as to take into account the anticipated incorne and the public expenses, to consider them in the project for the outgoing budget of the Federal District, to be sent to the Chamber of Deputies of the Congress of the Union.

C) Controlling: they receive the reports on the execution and completion of the budget of the Federal District and can deliver their comments on to the Federal Congress where it shall be considered during the revision of the Public Accounts of the Federal District.

D) Reganding the local judiciary: they have to approve the nomination of the Justices of the Superior Coun of Justice of the Federal District, made by the president of the Republic (formerly this task lay with the Chamber of Deputies). 
"To expedite laws that establish the concurrence of the Federal Government, of the Govemment of the States and of the municipalities, in the areas of their respective competences, with regard to environmental protection and the preservation and restoration of the ecological balance".

Based on this article the Congress expedited the beforementioned "General Law of Ecological Balance and Environmental Protection"45 which provides in its art. 9 that:

"In the Federal District the Federal Ministry (now SEDESOL) will exercise the attributions to which is referred in the anterior article (the general federal competence) and the Deparment of the Federal District will exercise the attributions that correspond to the local authorities, without prejudice to those within the competence of the Assembly of Representatives of the Federal District, in agreement with the following special dispositions; ..."

Schematically competences regarding the environment in the Federal District are divided as follows between federal institutions and local institutions:

\begin{tabular}{|c|c|c|c|c|}
\hline & $\begin{array}{l}\text { Execut } \\
\text { Authori }\end{array}$ & & $\begin{array}{l}\text { Legi } \\
\text { Auth }\end{array}$ & $\begin{array}{l}\text { ative } \\
\text { ities }\end{array}$ \\
\hline & Federal & Local & Federal & Local \\
\hline $\begin{array}{l}\text { Federal } \\
\text { Matters }\end{array}$ & SEDESOL & --- & $\begin{array}{l}\text { Federal } \\
\text { Congress }\end{array}$ & --- \\
\hline $\begin{array}{l}\text { Local } \\
\text { Matters }\end{array}$ & $\begin{array}{l}\text { Department } \\
\text { of the } \\
\text { Federal } \\
\text { District }\end{array}$ & --- & $\begin{array}{l}\text { Federal } \\
\text { Congress }\end{array}$ & $\begin{array}{l}\text { Assembly } \\
\text { of } \\
\text { Represent- } \\
\text { atives }\end{array}$ \\
\hline
\end{tabular}

Thus, the executive authority regarding the Federal District belongs exclusively to the Federal Authorities: on one side, conceming federal environmental matters SEDESOL is competent and on the other side, conceming local matters, the federal administrative organ, the Department of the Federal District is competent.

The legislative and regulatory authority conceming federal matters belongs to the Federal Congress but there is a dual legislative authority regarding local matters; on one hand the Assembly of Representatives is authorized to regulate local environmental affairs but on the

45 General Law on the Ecological Balance and the Protection of the Environment, D.O. 28 january 1988. 
other hand the federal SEDESOL is competent when it comes to the special dispositions of art. 9.

When comparing the different faculties as laid down in the comprehensive special dispositions, as is done in the following scheme, it is worth noting that in most cases for the federal authorities the principal words are "to determine and to expedite" and for the local authorities "to propose, apply, control and participate".

\section{Federal Competences SEDESOL}

Air

- To prevent and control the atmospheric pollution in the Federal District generated by permanent sources (with the exception of mercantile establishments or public spectacles), and to participate, conform the Agreement of Coordination which it concluded with the Federal District, in the prevention and control generated by movable sources which circulate through the territory of the Federal District;

- To expedite the technical norms for the maximum permitted emission of atmospheric pollutants by movable sources;

- To determine, in coordination with the Ministry of Commerce and Industrial Development and of Energy, Mines and Parastatal Industries the technology that will be applied to reduce polluting emissions from automotive vehicles;

- To expedite the technical ecological norms, that must be incorporated in the official mexican norms, for products that are utilized as combustibles or energetics in the Federal District;

- To establish and operate the monitoring network for atmospheric pollution in the Federal District.

\section{Competences of the Department of the Federal District / The Assembly of Representatives}
Air
- To prevent and control the atmospheric pollution in the Federal District generated by permanent sources, which function as mercantile establishments, public specta- cles and by all classes of movable sources which circulate through its territory; - To establish and operate inspection systems, with relation to the atmospheric pollution, for the vehicle park in the Federal District and if necessry, to limit the circulation of vehicles which exceed the maximum limits as determined by SEDE- SOL;
- To take the necessary measures to reduce the level of emission generated by motor vehicles;
- To control the compliance to the maxi- mum permitted emission norms for the public transport. 
Water

- To establish the norms for the discharge of the waste water of the sewage systems of the Federal District into receiving bodies;

- To expedite in coordination with the Ministry of Agriculture and Hydraulic Resources and the Ministry of Health, the technical norms to regulate the exploitation and use of waste water.

\section{Waste and Dangerous Substances}

- To expedite, in coordination with the Ministry of Health, the technical norms for the recollection, treatment and disposal of all classes of residues;

- To propose, in coordination with the Ministry of Health, to the Federal Executive in the dispositions that regulate activities related to dangerous materials or residues;

- To propose, in coordination with the Ministries of Agriculture and Hydraulic Resources, Health, and Commerce and Industrial Development, to the Executive dispositions that regulate the ecological effects of plaguicides, fertilizers and toxic substances;

- To prevent and control pollution of sources within federal jurisdiction originated by sound, vibrations, steam generated power, light and odours.

\section{Water}

- To operate the regional network of laboratories for the analysis of the atmospheric pollution;

- To apply the technical norms that are expedited by SEDESOL and the Ministry of Health, to regulate the discharge of water into the sewage system of the Federal District;

- To establish and develop, in coordination with the Ministry of Agriculture and Hydraulic Resources, the policy of the recycling of water in the Federal District;

- To implement and operate systems for the treament of waste water conform the corresponding technical norms.

\section{Waste and Dangerous Substances}

- To propose dispositions to the Federal Executive for regulation of activities related to the recollection, treatment and final disposal of non dangerous solid waste, observing the applicable technical ecological norms;

- To establish sites destined for the final disposal of the solid waste as mentioned above;

- To determine ecological criteria that will be incorporated in urban development programs and other policy instruments;

- To participate, within the sphere of their competence, in the formulation and execution of special programs established by the Federation, for the restoration of the ecological equilibrium in those zones and areas of the Federal District that present a grave ecological disbalance;

- To guard the observance of the resolutions that the Federal Executive expedites to regulate the use of the soil and of natural resources and the realization of activities 


\section{Evaluation}

- To evaluate the environmental impact of the realization of public works or activities to which is referred in the articles 28 and 29 of this law, which may affect or deteriorate significatively the ecological balance, conform the dispositions of this law, and to guard its observance.

\section{Emergencies}

- To propose to the Federal Executive the adoption of the necessary measures for the prevention and control of environmental contingencies and to apply them within the scope of their competences;

- To coordinate the application of the measures which are determined by the Federal Executive for the prevention and control of environmental contingencies by branches and entities of the Federal Public Administration.

\section{National Parks}

- To determine the bases of the organization and administration of national parks, and in coordination with the competent branches, of other ecological reservates in the Federal District. that cause pollution in the zones and areas of the Federal District that present a grave ecological disbalance;

- To prevent and control pollution caused by sound, vibrations, steam generated power, light and odours within the territory of the Federal District, except in case of sources that fall within federal jurisdiction.

\section{Evaluations}

- To evaluate the environmental impact of the realization of public works or activities to which is referred in article 28 of this law, and that do not fall under the scope of article 29, that may affect or deteriorate significatively the ecological balance, conform the dispositions of this law, and to guard its observance.

\section{Emergencies}

- To apply, within the scope of their competences, the measures as determined by the Federal Executive for the prevention and control of environmental emergencies and contingencies.

\section{National Parks}

- To participate, within the terms that are established by SEDESOL, in the organization and administration of national parks, and other ecological reserves in the Federal District. 


\section{Public Services}

-To observe the technical ecological norms when delivering public services of sewering, cleaning, markets, cemetries, slaughterhouses, transit and local transport.

\section{Control and Sanctions}

- To inspect, guard and impose sanctions within the sphere of their competences.

\section{Control and Sanctions}

- To inspect, guard and impose sanctions within the sphere of their competences.

SEDESOL and the Deparment of the Federal District will coordinate specifically the following matters:

- The development of programs to prevent and control the atmospheric pollution.

- The application of the standards issued by the federal authorities for plants and installations for the treatment of waste water within the Federal District to the effect that waste waters which flow from the territory of the Federal District to the territory of other federal entities, conform to the required technical ecological norms.

- The promotion of special programs for the restoration of the ecological balance in those zones and areas of the Federal District which present grave ecological disbalances, in coordination with the Ministry of Planning and within the scope of the Law of National Planning, to the Federal executive.

- The creation of protected natural areas in the Federal District.

- The promotion and development of participation of citizens in the various actions and programs to preserve and protect the ecosystem.

An exact reading of the special dispositions of art. 9 in combination with the earlier mentioned power of the Assembly to regulate local environmental matters, show that the Assembly's regulatory power regarding the environment is in fact restricted to:

1. atmospheric pollution generated by permanent sources, which function as mercantile establishments, public spectacles and by all classes of movable sources, including the limitation of the circulation and the reduction of the level of emissions by motor vehicles;

2. the establishment of the policy of the recycling of water;

3. the regulation of the discharge of water into the sewage system;

4. the determination of ecological criteria that will be incorporated in urban development programs and other policy instruments and

5. the prevention of pollution caused by sound, vibrations, steam generated power, light, within the territory of the Federal District.

Thus there remain large areas which the Assembly is not allowed to regulate, such as the norms for the discharge of waste water, the norms for the recollection and treatment of waste and so on. Consequently it is the Federal Congress acting as local Congress that 
should expedite a general law for the protection of the environment for the Federal District, leaving to the Assembly of Representatives the authority to expedite further executive regulations of this law. However, the (few) regulatory faculties of the Assembly make it difficult for the Federal Congress to present an overall law, so till the present day there is no general environmental law for the Federal District and environmental issues are dispersed over a number of federal and local regulations.

\subsection{The Metropolitan Zone}

The enormous growth of the population has de facto caused an expansion of the City's urbanised area over the original borders of the Federal District. Directly interlaced with the Federal District, Mexico City's urbanised area now extends over eighteen co-urban municipalities falling under the authority of the two States in which they are situated.

According to art. 5 and further of the 1988 General Law of Ecological Balance and Environmental Protection, in which is disposed what belongs to the competence of the states and municipalities, neither the federal govemment nor the government of the Federal District have authority over local environmental matters in the co-urban municipalities concerning the prevention and control of water and atmospheric pollution caused in zones or by sources of statal or municipal jurisdiction; the regulation of environmental effects caused by local public services such as the sewage and cleaning system, markets and provision centers, graveyards, transit and local transportation. Furthermore the regulation and final disposal of solid non toxic waste belong to statal and municipal competence.

Hence, it is possible that in the delegation Gustavo A. Madero (Federal District) and the connecting municipality Tlaneplante (State of Mexico) there are different regulations concerning the disposal of (non toxic) waste, with all the consequences entailed.

This problem of diverging norms was especially cogent with the air pollution, caused inter alia by the millions of automobiles circulating daily through the City. Diverging technical standards in the Federal District and her respective co-urban municipalities did not add to an effective policy.

In order to reduce the atmospheric pollution caused by private automobiles first of all it seemed necessary to limit the circulation of vehicles and to limit the emission of pollutants by vehicles through setting technical standards. Within Mexico City the power to issue such regulations was divided thus that in the territory of the Federal District the Assembly of 
Representatives, in cooperation with the Department of SEDESOL ${ }^{46}$ was competent. In the co-urban municipalities the respective states and municipalities were authorized to regulate this issue.

However, in this particular case a unique piece of legislation was created in order to beget a coherent regulation for all of Mexico City's urbanized area. It was recognized that the problem of pollution by vehicles did not limit itself to the borders of the Federal District but extended to a wider zone. Through the joint efforts of SEDUE (now SEDESOL), the Department of the Federal District and the Government of the State of Mexico incollaboration with the municipalities of the Co-urban Zone, the battle of competences was overcome47, and the "Regulation to the Law for the Prevention and Control of Pollution Generated by Automotive Vehicles that Circulate through the Federal District and Municipalities in its Co-urban Zone"48 was issued.

In this case, although strictly speaking the regulation of movable sources belongs to the competence of the Federal District and the respective states and municipalities, a federal regulation was made that is only valid locally. Nevertheless it remains an open queston whether this federal regulation is constitutional, since the Federal Authorities are not empowered to legislate in this matter over the States or over the Federal District. Thus theoretically anybody could refuse to comply and start a legal procedure of judicial review (amparo ex art. 103 Constitution) against the inconstitutionality of the said regulation.

\section{Conclusion}

One of the aspects that has obstructed an effective environmental legislation for Mexico City is the fragmentatoin of legislative authority. First of all looking at the Federal District, the particular way in which legislative authority on local environmental matters is distributed between federal and local authorities is one of the main reasons that until now there is no general environmental law for the Federal District; to the contrary, the law is dispersed over various, sometimes contradictory decrees and regulations.

Secondly, to look at Mexico City's environmental problems it is not enough to restrict oneself to the Federal District, it would be wise to include Mexico's Metropolitan Zone, not on an incidental basis as occurred in the case of vehicles circulating through the City, but

46 See the "Regulation to the General Law of Ecological Balance and Environmental Protection regarding the Prevention and Control of Atmospheric Pollution", published D.0. 25-11-1988.

47 This cooperation between the different authorities seems to have happened on an informal basis, at least in the Regulation itself no mention is made of the existence of a Coordinating Commission with own responsibilities for Mexico City as a whole.

Published D.O. 25-11-1988. 
structurally, to centralize legislative authority in environmental affairs, as these are too multi-facetted and complicated to handle by each local authority.

This could call for a change of the Mexican Constitution, whereby the federal authorities represented by SEDESOL, would get the authority to plan and legislate in cooperation with the local authorities in both the Federal District and the Metropolitan Zone. Hence, it would be useful to create an Intergovemmental Council for Environmental Matters in Greater Mexico City, falling under the auspices of SEDESOL, in which all interested govemment parties are represented and which is headed by the president of the National Ecological Institute. The Councils particular task would be to coordinate the different demands and priorities and to advise SEDESOL on the necessary measures. 


\title{
ABSTRACTS
}

\section{Notes on the Commission on Human Rights and Administrative Justice under the 1992 Ghanaian Constitution}

\author{
By Joseph R.A. Ayee
}

One of the institutions created under the 1992 Ghanaian Constitution to promote and saf eguard public accountability and human rights is the Commission on Human Rights and Administrative Justice (CHRAJ). The paper discusses the powers and jurisdiction, procedures in respect of investigations and financial position of the CHRAJ in relation to previous ombudsman experiment in Ghana. The paper concludes with a number of recommendations.

The Legal and Administrative Context of Environmentai Policy in Mexico City

\section{By Brigitte F.P. Lhoëst}

It is a well known fact that Mexico City's environmental problems are enormous. However, the complexities of environmental issues facing the Mexican authorities are matched if not outdone by the convoluted govemmental and legislative structures in place to deal with them.

Mexico City is not an ordinary municipality but consists of a separate political and administrative entity in its own right, the Federal District and of a Metropolitan 7one composed of eighteen co-urban municipalities situated in two separate states, the State of Mexico and the State of Hidalgo.

It is the aim of this article to demonstrate that the fragmentation of legal authority to deal with environmental problems in Mexico City effectively vitiates an adequate govemment response towards containing let alone solving environmental problems.

For this purpose regard will first be had to the development of the national legislation, the administrative structure and the competences of the Federal Government concerning the environment. Next, the environmental legislation of Mexico City will be considered. Finally the consequences of the present fragmentation of legislative power regarding the environment will be contemplated. 